\title{
56. MINERALOGY OF THE CLAY FRACTION OF THE ATLANTIC OCEAN SEDIMENTS, DSDP LEG 48
}

\author{
P.P. Timofeev, M.A. Rateev, and N. V. Renngarten, Geological Institute of the USSR Academy of Sciences, Moscow
}

\begin{abstract}
Thorough study of the mineralogy of clay matter retrieved from DSDP drill sites is important in understanding the geological development of the sea floor. This report deals with: (1) the stratigraphic age distribution of clay minerals in sections of the Leg 48 holes; (2) bonds of clay mineral associations with lithological types of rocks and volcanism; and (3) features of formation of clay mineral associations.

The mineralogical composition of the clay fraction of sediments and rocks of Leg 48 was studied on Sites 403, 404, 405 , and 406 in the vicinity of Rockall Plateau, and on Sites 401 and 402 of the Bay of Biscay. The $<0.01 \mathrm{~mm}(<10 \mu \mathrm{m})$ clay fraction was studied because it most fully reflects the composition of pelitic particles in a rock. The identification of some species of layer silicates was conducted with X-ray diffractograms which had been prepared by means of diffractometer "DRON-1"' on $\mathrm{Cu} \mathrm{K} \alpha$ radiation, tension 35 $\mathrm{kw}$ and $20 \mathrm{ma}$. The scanning rate was 2 degrees per minute. The survey was performed for the three states of a sample: natural (i.e., air-dried), saturated with glycerine, and heated at $550^{\circ} \mathrm{C}$. For distinguishing the chloritic phase from the kaolinitic one, the treatment of samples with 10 per cent $\mathrm{HCl}$ was used.
\end{abstract}

As a result of the X-ray study of the clay fraction in Meso-Cenozoic deposits of Leg 48, the following minerals have been recognized: montmorillonite, illite, Fe- $\mathrm{Mg}$ trioctahedral chlorites, and mixed-layer minerals with varying ratios of montmorillonitic and illitic layers. Among these, the best distributed are disordered (M-i) with a sharp predominance of expansible layers (roughly up to 80 to $90 \%$ ). Less frequent are the varieties (i-M) with predominance of illitic layers up to 70 to 90 percent. Rarer mixed-layer minerals with a disordered alternation of chloritic and montmorillonitic (Ch-M) and chlorite-vermiculitic ( Ch-V) layers were found as a small admixture.

The X-ray characteristic of kaolinite, Fe-Mg-trioctahedral chlorite, and montmorillonite did not show significant differences from standard minerals (Brindley, 1951; Micheev, 1957), except for high dispersion which, in the case of montmorillonite, is responsible for expansion after saturation with glycerine $\mathrm{c} \mathrm{d} / \mathrm{n}>18 \AA$ (Reynolds, 1968).

The identification of mixed-layer minerals was carried out on the basis of works by Brindley (1951), MacEwan (1955), Mering (1950), Sato (1965), Reynolds (1967, 1968), Drits and Sakharov (1976), and Gradusov (1975).

Among mixed-layer minerals of Leg 48 samples, minerals with disordered alternation of montmorillonitic and illitic layers (with predominance of expansible packets up to 80 to $90 \%$ ) are characterized by the presence of diffraction maxima: 13.7 to $14.7 \AA$ for an air-dried specimen, 18.4 to $19.0 \AA$ for samples saturated with glycerine, and 9.93 to 10.0
$\AA$ for sediment heated at $550^{\circ} \mathrm{C}$, with an appreciable asymmetry from the side of small angles (Figure 1).

Mixed-layer minerals with disordered alternation of illitic and montmorillonitic (i-M) layers, with sharp predominance of illitic packets (up to 85 to $90 \%$ ), were identified by means of the basal reflex $10.0 \AA$ for a natural specimen, 9.8 to $9.9 \AA$ when saturated with glycerine, and 9.9 to $10.0 \AA$ when heated at $550^{\circ} \mathrm{C}$ (Drits and Sakharov, 1976). Such minerals can be also regarded as slightly expansible illites, but we single them out as a group of mixed-layer minerals. The mixed-layer mineral of the chlorite-vermiculitic ( $\mathrm{Ch}-\mathrm{V})$ type with a disordered alternation of chloritic and vermiculitic packets can be determined by means of reflex values 14.2 to $14.4 \AA$ for an air-dried specimen, $14.2 \AA$ when saturated with glycerine, and 9.5 to $14.2 \AA$ when heated at $500^{\circ} \mathrm{C}$. In addition, the mineral can be dissolved in $\mathrm{HCl}$ and have do60 $\approx 1.53 \AA$.

Mixed-layer minerals of the chlorite-montmorillonitic (Ch-M) type with a disordered interstratification of chloritic and montmorillonitic layers are identified by means of reflexes 14.2 to $15.5 \AA$ for an air-dried specimen, $17.8 \AA$ when saturated with glycerine, and 12.5 to $13.6 \AA$ when heated at $500^{\circ} \mathrm{C}$ one (Gradusov, 1975).

Besides clay minerals, the $<10 \mu$ m clay fraction contains zeolites; clinoptilolite is the most widely distributed; phillipsite and analcime are found less frequently.

\section{STRATIGRAPHIC DISTRIBUTION OF CLAY MINERALS IN DRILLED INTERVALS OF THE ROCKALL PLATEAU REGION}

Stratigraphic association of clay minerals in sections of the Rockall Plateau holes and their consanguinities with facies types of rocks are described upwards from downhole, corresponding to the history of geological development of the region.

\section{Hole 403}

The lowermost part of the cored interval (Cores 43 to 48) consists of dark gray, coaly, sandy-silty rocks, and is early Eocene in age. These sediments have the chloritic-montmorillonitic composition of the clay fraction, and contain an admixture of mixed-layer minerals with disordered alternation of chloritic and montmorillonitic (Ch-M) packets (Figure 2), likely developing after biotite.

The composition of lower Eocene greenish gray tephroid rocks (Cores 38 to 42 ) is mostly montmorillonitic with an admixture of zeolites, usually clinoptilolite.

The composition of sandy-clayey siltstones (Cores 31 to 37 ) of the lower Eocene is a mixed-layer montmorillonite-il- 


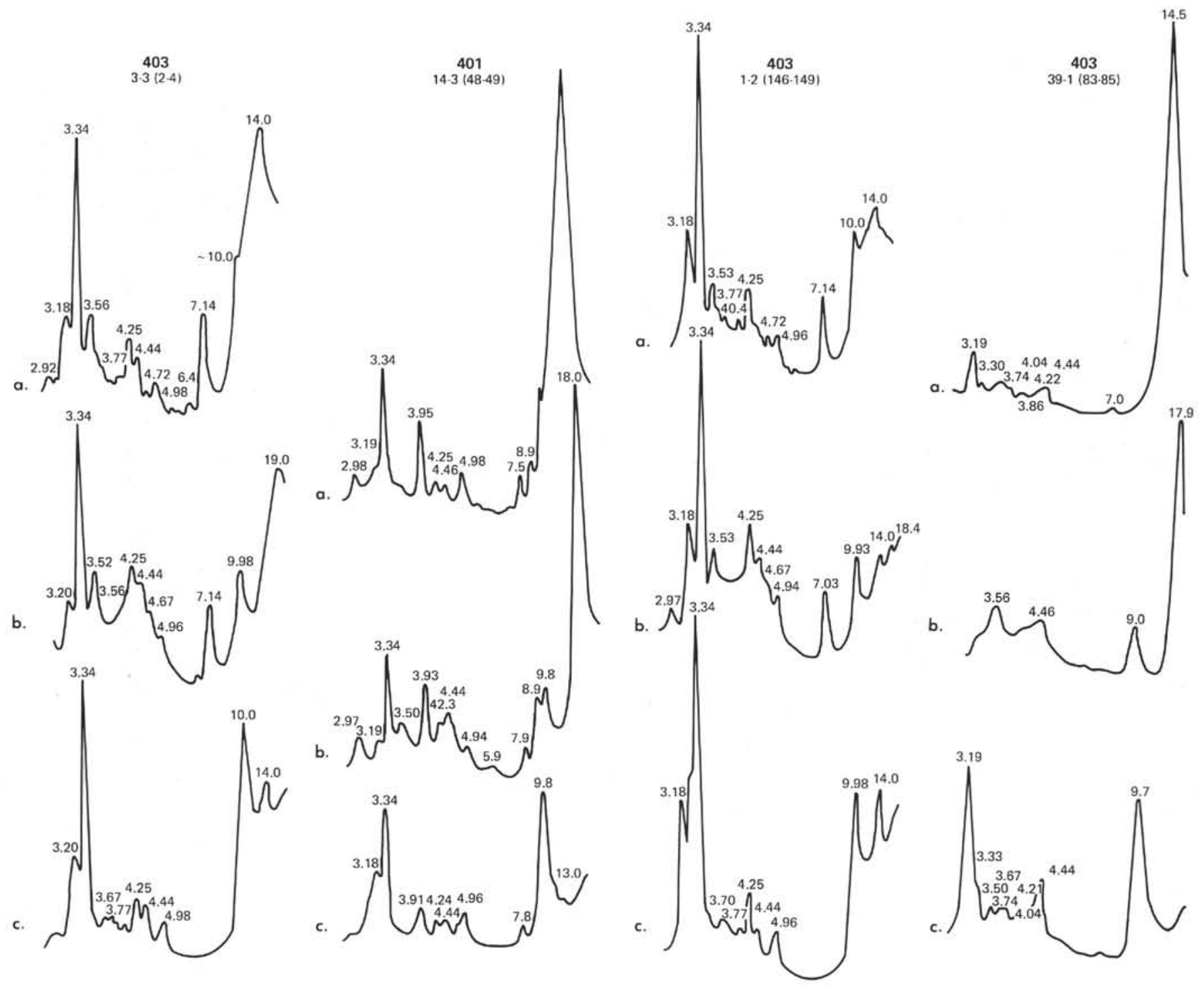

Figure 1. X-ray diffractograms of typical clay minerals. Sample 403-3-3, 2-4 cm, mixed-layer montmorillonitic-hydromicaceous $(M-H)$ mineral with predominance of expansible montmorillonitic packets and an admixture of hydromica and chlorite; Sample 401-14-3, $48-49 \mathrm{~cm}$, mixed-layer hydromicaceous montmorillonitic (H-M) mineral with predominance of hydromicaceous packets associated with montmorillonite; Sample 403-1-2, 146-149 cm, polymineral association with chlorite, hydromica, and a small admixture of montmorillonite; Sample 403-39-1, 83-83 cm, montmorillonitic mineral. Note: $a=$ air-dried, $b=$ with glycerine, $c=$ heated at $550^{\circ} \mathrm{C}$.

itic (M-i) mineral in the clay fraction, or montmorillonite with a small admixture of illite and chlorite.

Lower Eocene deposits (Cores 29 to 31), comprised of greenish black tephroid rocks, have a montmorillonite composition with an admixture of clinoptilolite.

The middle Eocene and upper-middle Oligocene deposits (Cores 25 to 28 , inclusive) are characterized by intense development of a green glauconite-like mineral of the mixed-layer, that has a montmorillonite-illitic composition (Sample 403-28-1, 89-92 cm).

The composition of the upper Miocene deposits (Cores 10 to 24) consists of light gray nannofossil foraminiferal marls with the clay fraction having polymineral composition of montmorillonite, illite, and chlorite. Upper Miocene deposits (Core 9) consist of foraminiferal nannofossil oozes of montmorillonitic composition.

Sediments from the lower and upper Pliocene and the lowermost Pleistocene (Cores 3 to 8 ) consist of foraminiferal nannofossil oozes having polymineral composition, with the mixed-layer (M-i) mineral predominating, and lesser amounts of illite and chlorite.

Upper Pleistocene sediments (Cores 1 to 3) are foraminiferal nannofossil oozes and clays with unsorted clastic material showing evidence of ice transport. These 


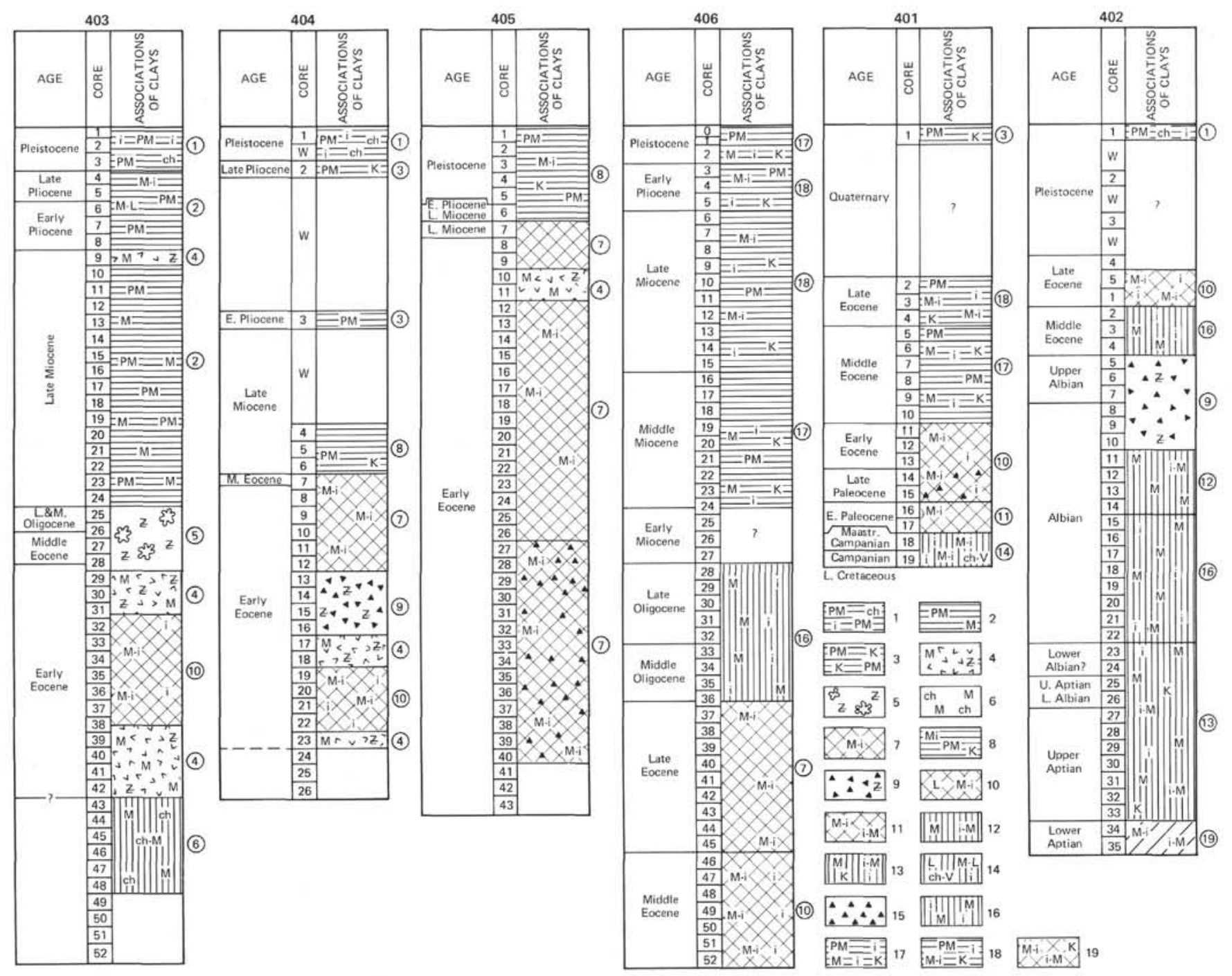

Figure 2. Association of clays in various DSDP cores, with corresponding ages indicated. $M-i=$ mixed-layer montmorillonite-illitic mineral; $i=$ illite-montmorillonitic mineral; $C h-M=$ chlorite-montmorillonitic mixed-layer mineral; $M=$ montmorillonite-smectite; $i=$ illite (hydromica); $k=$ kaolinite, $Z=z e o l i t e ; P M=$ polymineral association. 1 = polymineral, hydromicaceous chloritic, $2=$ polymineral, hydromicaceous-chlorito-montmorillonites, $3=$ polymineral, chlorite-hydromicaceous with kaolinite, $4=$ montmorillonitic with zeolite, 5 = glauconitic with zeolite, $6=$ chlorite-montmorillonitic with mixed-layer $(C h-M)$ mineral, $7=$ mixed-layer montmorillonite-hydromicaceous $(M-i), 8=$ polymineral, hydromicaceous-chloritic (sometimes with montmorillonite), $9=$ zeolitic-siliceous, $10=$ mixed-layer $(M-i)$ with hydromica, $11=$ mixed-layer with two types of minerals $(M-i$ and $i-M), 12=$ mixed-layer $(i-M)$ and montmorillonitic, $13=$ hydromicaceous-montmorillonitic with kaolinite, $14=$ hydromicaceous mixed-layer $(M-i)$ and $(C h-V), 15=$ silicification (crystobalite and tridymite), $16=$ hydromicaceous-montmorillonitic, $17=$ polymineral hydromicaceous-montmorillonitic with kaolinite, 18 = polymineral-hydromicaceous mixed-layer $(M-i)$ with kaolinite, $19=$ mixed-layer with two types of minerals ( $M-i$ and $i-M)$ and kaolinite. 
deposits have a more pronounced polymineral composition in the clay fraction, with an abundance of illites and chlorites, and an appreciable admixture of montmorillonite.

\section{Hole 404}

The distribution of clay minerals in Hole 404 is generally similar to that of Hole 403 .

Tephroid rocks (Core 23) of early Eocene age, in the lower part of Hole 404, have the montmorillonitic composition as do synchronous sediments of Hole 403, with clinoptilolite being more frequently recognized here.

The clay fraction of lower Eocene, sandy-silty deposits (Cores 19 to 22) is composed of montmorillonite and (in some interbeds) a mixed-layer montmorillonitic-illitic (M-i) mineral.

Tephroid rocks in the lower Eocene (Cores 17 to 18) have a montmorillonitic composition with an admixture of zeolite.

The clay fraction of lower Eocene tuffogene organogeniccarbonate-siliceous deposits (Cores 13 to 16) abounds in siliceous minerals (cristobalite and tridymite) with a slight admixture of montmorillonite or a mixed-layer montmorillonite-illitic (M-i) mineral.

Tuffogene spongolite-diatomites of the upper and middle Eocene deposits (Cores 7 to 12) have a mixed-layer montmorillonitic-illitic (M-i) composition in the clay fraction.

Foraminiferal nannofossil oozes of the upper Miocene (Cores 3 to 6) have clay fractions of polymineral composition with illite, chlorite, and an admixture of the mixed-layer (M-i) mineral.

Quaternary deposits (Cores 1 to 2) presented by foraminiferal nannofossil oozes (with clastic material that was transported by ice) have, as in Hole 403, a well-pronounced polymineral composition of the clay fraction. These deposits contain chlorite, illite, and an admixture of the mixed-layer $(\mathrm{M}-\mathrm{i})$ mineral or montmorillonite.

\section{Hole 405}

A thick interval of lower Eocene rocks (Cores 12 to 40) include siltstones, clays, and diatomites. The clay fraction of these deposits has a monotonous mixed-layer (M-i) composition.

Lower Eocene foraminiferal nannofossil oozes (Cores 10 and 11) have the montmorillonitic composition of the clay fraction, with an admixture of zeolite. Deposits from the lower Eocene/Miocene deposits (Cores 7 to 9) have the mixed-layer (M-i) composition of the clay fraction.

Foraminiferal nannofossil oozes (Cores 1 to 6) contain an admixture of sandy-silty material (derived from ice transport) and are early Pliocene and Pleistocene in age. These deposits have a well-pronounced polymineral composition of the clay fraction including illite and chlorite. The mixed-layer (M-i) mineral or kaolinite is observed as a small admixture.

\section{Hole 406}

The middle Eocene deposits (Cores 47 to 51) consist of marls and, less frequently, limestones containing a mixedlayer (M-i) mineral, with an admixture of illite as a separate phase.
The $<10 \mu \mathrm{m}$ fraction of the upper part of the middle Eocene (Core 46) is composed of clay limestones with foraminifers, and contains ferruginous montmorillonite (which decomposed in $10 \% \mathrm{HCl}$ in one hour).

In upper Eocene foraminiferal limestones (Cores 37 to 45), the clay fraction is rich in mixed-layer minerals of montmorillonite-illitic (M-i).

The clay fraction in middle and upper Oligocene sediments of nannofossil and Ethmodiscus oozes (Cores 28 to 35) is rich in montmorillonite with an admixture of illite.

Middle Miocene foraminiferal nannofossil chalk (Cores 16 to 24) contains montmorillonite in the clay fraction, or a strongly expansible mixed-layer montmorillonite-illitic (M-i) mineral with a slight admixture of kaolinite and sometimeș illite.

In upper Miocene/lower Pliocene foraminiferal nannofossil chalk and oozes (Cores 3 to 15), the clay fraction contains a polymineral complex: mixed-layer montmorillonite-illitic (M-i) mineral with an admixture of illite, kaolinite, and sometimes chlorite.

Pleistocene foraminiferal nannofossil oozes (Core 2) are also characterized by the polymineral composition of the clay fraction: montmorillonite, illite, kaolinite, and an admixture of chlorite.

\section{THE BAY OF BISCAY REGION}

As already mentioned in the lithological description, the holes drilled in the Bay of Biscay penetrated older deposits than those of the Rockall Plateau region.

\section{Hole 401}

Campanian/Maestrichtian white pelitomorphic limestones (Cores 18 and 19) contain a clay fraction that is rich in illite. Secondarily, there are mixed-layer (M-i) minerals with a predominance of expansible layers. Less frequently, there is a small admixture of chlorite, mixed-layer minerals of the chlorite-vermiculitic (Ch-V) type, clinoptilolite, quartz, and feldspars (Figure 2).

Upper Paleocene deposits (Cores 16 and 17) of pinkish gray pelitomorphic limestones with foraminifers are characterized by a predominance of two types of mixed-layer minerals ( $\mathrm{M}-\mathrm{i}$ and $\mathrm{i}-\mathrm{M})$, with an abundance of either expansible or illitic packets in the clay fraction. In addition, there is an admixture of chlorite, clinoptilolite, and quartz.

Upper Paleocene and lower Eocene deposits (Cores 11 to 15) of pinkish compact pelitomorphic limestones with foraminifers contain a clay fraction composed of two minerals: montmorillonite (prevailing) and mixed-layer (i-M) mineral. There is a small admixture of kaolinite, chlorite, clinoptilolite, and quartz.

Middle Eocene deposits (Cores 5 to 10 ) of greenish gray compact limestones (with foraminifers and siliceous remains) are composed mostly of montmorillonite and illite, with a small insignificant admixture of kaolinite, chlorite, clinoptilolite, and quartz.

Upper Eocene deposits (Cores 2 to 4 ) of nannofossil oozes (with diatoms, sponge spicules, and foraminifers) differ in composition of the clay fraction from underlying deposits of the middle Eocene in the prevalence of a mixed-layer (M-i) 
mineral and illite. Admixtures of kaolinite, clinoptilolite, and quartz are insignificant.

Finally, Quaternary deposits (Core 1) of marly, sandy-silty nannofossil oozes are characterized by a better pronounced polymineral composition of the clay fraction. The composition is mainly illite, with chlorite and kaolinite in smaller amounts. Montmorillonite, a mixed-layer (M-i) mineral, illite, and quartz were observed but are a nearly negligible admixture.

\section{Holes 402 and 402A (summarized section)}

The clay fraction of lower Aptian deposits (Cores 34 to 35) are greenish gray, slightly silty coaly marls in Hole 402A. These deposits contain two types of mixed-layer minerals ( $\mathrm{M}-\mathrm{i}$ and $\mathrm{i}-\mathrm{M})$ and kaolinite.

Upper and lower Albian deposits (Cores 23 to 33) of silty, coaly clays are characterized by predominance in the clay fraction of montmorillonite, presence of a mixed-layer (i-M) mineral with prevalence of illitic packets, and an admixture of kaolinite and chlorite.

The clay fraction of Albian coaly-silty clays (Cores 15 to 22) contains montmorillonite; illite; and an admixture of kaolinite, clinoptilolite, cristobalite, and quartz.

Albian carbonate-siliceous tuffogene-clayey rocks (Cores 11 to 14) contain in their clay fraction montmorillonite and mixed-layer (i-M) mineral, with an admixture of siliceous minerals (cristobalite, tridymite, or opal-ST).

In upper Albian deposits (Cores 5 to 10 ) of dark gray carbonate-siliceous rocks, the clay fraction consists of silica (cristobalite and tridymite) and an admixture of mixed-layer minerals (M-i or i-M) or of clinoptilolite.

In middle Eocene deposits (Cores 2 to 4 ) of spongolitic nannofossil oozes, the clay fraction is composed of montmorillonite with an appreciable admixture of illite and a small admixture of chlorite.

The clay fraction of upper Eocene deposits (Cores 402A-1 and 402-5) is lithologically similar to underlying ones, and contains predominant mixed-layer (M-i) mineral, illite, and traces of chlorite.

The upper part of Pleistocene sediments (Core 402-1) of interbedded foraminiferal nannofossil oozes and silty clays has a well-pronounced polymineral composition of the clay fraction. The fraction is rich in illite and chlorite, with a small admixture of montmorillonite and quartz.

\section{FEATURES OF FORMATION OF CLAY MINERAL ASSOCIATIONS AND THEIR CONSANGUINITIES WITH FACIES-LITHOLOGICAL ROCK TYPES}

The formation of clay mineral associations of rocks is most closely related to both the source rocks and the general process of sedimentation.

As a result of studying the clay minerals in deposits penetrated during Leg 48, the following genetic types of the clay fraction can be established: (1) authigenic sediment and diagenetic montmorillonite (from basic volcanic material) and a diagenetic glauconite-like mineral (vitroclasts of a more acid composition); (2) transformation matter after $\mathrm{Fe}-\mathrm{Mg}$ micas of the trioctahedral biotitic series, including mixed-layer minerals of the chlorite-montmorillonitic (Ch-M) and chlorite-vermiculitic (Ch-V) types; and (3) detrital clay minerals (i.e., illites, chlorite, kaolinite, and montmorillonite) related to proximal and distal transport by currents, or ice transport of coarse detrital and clay material in the Pleistocene. The clay mineral associations owe their formation to activity of one or more factors of sedimentation under various facial conditions and in different geological epochs.

\section{CONSANGUINITIES OF MONTMORILLONITE WITH VOLCANISM}

In the lower Eocene deposits of the Rockall Plateau region, one can clearly observe a direct consanguinity of montmorillonite with the rocks formed at the expense of redeposition and reworking of vitroclastic and pyroclastic material of the basic (basaltic) composition. We call these rocks tephrogene, after Rittman (1960).

Interbeds of tephrogene rocks and partly tuffaceous claystones are especially well pronounced in sections from Sites 403 (Cores 39 to 42 and 29 to 31 ) and 404 (Cores 23 and 17 to 18 ). The clay fraction of these rocks is characterized by purely montmorillonitic composition associated with clinoptilolite and rarely with analcime, without any admixture of other clay minerals. The process of montmorillonite formation related to decomposition and substitution of the basic volcanic glass (as found in Eocene sediments of the Rockall Plateau) has been long known, but its mechanism has not been studied adequately. Volcanic glasses of basic basaltic composition were considerably quicker and more readily decomposed while passing into montmorillonite than were acid varieties. Acid volcanic glasses lend themselves to decomposition processes with greater difficulties. Thus, for example, there are data by Neeb (1943) testifying to the presence of fresh grains of acid volcanic glasses in recent sediments without any traces of changes.

Therefore, when speaking of stages of rock formation, basic volcanic glasses may change as early as during transport and initial deposition, i.e., in sedimentogenesis and early diagenesis. During montmorillonitization of relatively coarse grains of volcanic glass (of sandy-silty size), there appears peculiar aggregate polarization, but with preservation of a considerable part of the roentgen-amorphous matter.

The same process in finer vitroclastic material of the clay fraction is proceeding with replacement of glassy particles by montmorillonite, with optical and roentgenographic constants that are specific to this process.

However, if in Eocene deposits of the Rockall Plateau, montmorillonite shows direct consanguinity with volcanism, its consanguinity is indirect in Mesozoic deposits penetrated by drillsites in the Bay of Biscay. In the Bay of Biscay, montmorillonite is a redeposition product of older volcanogenic sediment from the nearest land. Being in the Mesozoic, the chief component of the clay fraction is associated not with volcanic glass, but with a constant kaolinitic admixture that appreciably increased in silty interbeds.

\section{INITIAL GLAUCONITIZATION}

If montmorillonite is intensely developing from the basic volcanic glass in the Eocene deposits of the Rockall Plateau, a green glauconite-like mineral is formed in the middle 
Eocene/Oligocene sediments enriched with vitroclastic material of a more acid composition that is similar to the andesite-basaltic material. This process is especially obvious in tuffitic rocks penetrated at Site 403 (Cores 25 to 28) in the interval associated to the lower-middle Eocene boundary (Sample 403-28-1, 89-92 cm). Without going into the details of the glauconitization process described by Odin and Harrison (this volume), we want to emphasize some factors important for the given process: its relation with volcaniclastic material (more acid than common basalts), mixed-layer structure of the mineral and its heterogeneity, possible addition of $\mathrm{K}_{2} \mathrm{O}$ into ooze waters (due not only to decomposition of acid volcaniclastic material, but biotite as well), and an optimal, slightly reducing environment of diagenesis.

The glauconite-like mineral has a rather peculiar microscopic appearance here, green in color and typically with authigenic patches having the shape of irregular grains sized up to $0.5 \mathrm{~mm}$. They are usually cut by desiccation fissures occurring as a result of dehydration and the processes of " aging"' of primarily colloidal matter. The green glauconitic-like mineral covers grains of quartz and feldspar, forming concentric rims around them. It completely replaces some diatom remains, penetrates into sponge spicule canals, or fills cavities of foraminiferal tests. Yet, despite the outer resemblance, the crystalline structure of this glauconite-like mineral is far from that of a true glauconite.

According to X-ray data by V. A. Drits, the mineral has a mixed-layer structure with strongly predominant montmorillonitic expansible layers disorderly alternating with rare packets of ferruginous glauconite-like illite that are diagnosed after $d_{060} 1.505$ to $1.510 \AA$, and make up not over 5 to 10 per cent of the mixed-layer glauconite-like mineral. The formation of this mineral is of interest as the most initial stage of early diagenetic transformation of well-dispersed, volcanogenic montmorillonite into glauconite.

The essence of sedimentary-diagenetic glauconitization (data by Shutov et al., 1975) consists in entering, accumulation, and fastening of potassium cations in the crystalline lattice of montmorillonite, with a parallel increase of $\mathrm{Fe}^{+++}$cations in octahedra and a decrease of Alvı.

The intensity of glauconitization probably can become stronger in cases when the increase of potassium cation concentration in interstitial solutions takes place not only at the expense of decomposition of vitroclastic material, but also due to solution of the biotite present in the sediment.

The study of glauconite mineralogy of some USSR deposits with the help of the so-called "gradient" tube (Shutov et al., 1972) in fractions of various density enabled us to establish heterogeneity of glauconite particles in one sample. This heterogeneity is related to fine variations of the physicochemical medium of their formation, transformation of organic matter, variations of $p \mathrm{H}$ and Eh values, etc. in the slightly reducing environment of diagenesis. This testifies to the extremely complicated mineralogy of this mineral.

\section{PRODUCTS OF TRANSFORMATION OF TRIOCTAHEDRAL MICAS OF THE BIOTITIC SERIES}

Products of transformation of metastable trioctahedral micas were recognized in fine-grained coaly sandstones underlying lower Eocene sediments (Site 403, Cores 43 to 48) and in Campanian-Maestrichtian organogenic-clastic limestones from Site 401 (Cores 18 and 19).

Microscopic study of these rocks clearly showed splitting of large, relatively fresh, biotite plates into smaller scales; the loss of color in these plates with evacuation of iron; and their transformation into authigenic, newly formed, intermediate products. These products (diagnosed by means of radiography in the clay fraction of the given rocks) contain the following mixed-layer minerals: (1) disordered alternation of chloritevermiculitic (Ch-V); (2) chlorite-montmorillonitic (Ch-M) layers; and (3) illite-montmorillonitic (i-M) dioctahedral minerals. The transformation of biotite via vermiculite and chlorite into montmorillonite (performed through a series of mixed-layer phases) has been structurally studied by Kossovskaya and Drits (1970) and others. A significant peculiarity pointed out by Kossovskaya and Drits (1970) is the dioctahedrization of newly formed components, including montmorillonite and illite of the IMd type, resulting from modification of biotite in sedimentary rocks.

Under conditions of oceanic sedimentation, the process of transformation of biotite is more intense in deeper water zones, and less intense in relatively shallow-water sediments. This may mean that structural transformations of biotite were mostly proceeding at the early diagenetic stage. Considering instability of biotite, we can assume that only an insignificant part of fine-dispersed clay products of its subaerial decomposition was brought from land into the sedimentation area; its partial decomposition could have occurred as early as during transport, i.e., at the stage of sedimentogenesis.

\section{INFLUENCE OF ICE TRANSPORT OF SANDY-CLAYEY MATERIAL ON THE FORMATION OF PLEISTOCENE SEDIMENTS}

In the lithological study of Pleistocene (relatively deep-water) sediments of Leg 48 , attention was paid to unsorted clastic material of varied petrographic composition and dimensionality. This unsorted material of Pleistocene sediments, combined with the well-pronounced polymineral composition of their clay fraction, was distributed by drift ice not only in the North Atlantic, but reached $43^{\circ}$ to $45^{\circ} \mathrm{N}$ latitudes corresponding to the northern boundary of Spain. This can be confirmed by the data of Barasch (1974) on distribution of thanatocoenoses of planktonic foraminifers of the subarctic type. Their southern boundary (during the upper maximum of the last continental glaciation) came down southwards to the latitudes of the northern coasts of Spain in the eastern part of the ocean, and to the Azore islands in the western part. This boundary coincides with the area of distribution of unsorted clastic material. The data by Barasch (1974) are also confirmed by our studies of Legs 48, 49, and 45. Thus, if clastic material transported by ice is coarser in Pleistocene sediments of the Rockall Plateau, and finer (but still recognizable) in holes of the Bay of Biscay and in Hole 410 (Leg 49), it is hardly observable in the uppermost parts of the Pleistocene. In sections of Holes 411 and 412 (Leg 49) and Holes 395 and 396 (Leg 45), no ice-transported material was found. The formation of sandy-silty, as well as the clay fraction of Pleistocene sediments, was probably influenced 
by drift-ice transported materials (morainic, etc.) from Arctic areas. This influence is found, first of all, in their well-pronounced polymineral character and abrupt variations of the quantitative relationships of minerals in vertical sections.

The clay fraction of Pleistocene sediments from Sites 401 and 402 of the Bay of Biscay is composed of abundant illite; from Site 404, of chlorite; and from Site 403, of strongly expansible mixed-layer montmorillonite-illitic (M-i) minerals to montmorillonite. Along with these minerals, but in lesser amounts, montmorillonite and kaolinite are distributed.

The influence of ice transport on the formation of the clay fraction of Pleistocene sediments is obvious by comparing semiquantitative values of the mineralogical composition of their clay fraction to those of recent sediments. The comparison of semiquantitative data on the mineralogical composition of the clay fraction in recent sediments (after Biscaye, 1964; Griffin et al., 1968) to data on Pleistocene deposits of the Rockall Plateau region and the Bay of Biscay (obtained by us) shows increased amounts of chlorite (up to $30 \%$ ) in Pleistocene sediments. This appears related to a more intense redeposition of chlorite in the Pleistocene from metamorphic schists of Greenland and Scandinavia, with participation of glaciers sliding into the sea and farther transport of clay material by drift ice. The kaolinite content is more or less the same both in the Pleistocene and the recent sediments (tentatively, 10\%). In this case, this is probably related to its inheritance, rather than to climatic factors.

\section{CONCLUSION}

The mineralogical study of the clay fraction of Leg 48 oceanic sediments established the following:

1) In the Rockall Plateau, the lower Eocene sediments of mobile shallow-water sedimentation display a direct consanguinity between montmorillonite and volcanism. The mechanism of its formation is related to montmorillonization of the basaltic lava fragments (i.e., tephrogene rocks) and their cementation by montmorillonite together with zeolite, without any admixture of detrital minerals.

Abundance of montmorillonite (formed at the expense of decomposition of the basic volcanic material) testifies to more significant intensity of volcanism in early Eocene time in the region of disposition of Rockall Plateau (Sites 403 and 404). Active basaltic under-water volcanism was associated here with intensification of tectonic movements.

In the Bay of Biscay region (Site 402), the Mesozoic, near-shore sediments display consanguinity between montmorillonite and volcanism that is of indirect character. Montmorillonite, being the chief component of the clay fraction of silty-clayey sediments here, was combined with a small admixture of kaolinite (its amount increasing in silty interbeds). This testifies to its redeposition due to wash-out of near-shore rocks.

2) The initial process of glauconitization of volcanogenic montmorillonite into a mixed-layer mineral with appearance of structural packets of ferruginous glauconite-like hydromica with extraction of potassium cations from interstitial waters as a result of dissolution of vitroclastic material of andesite-basaltic composition, or unstable biotitic micas.
3) Distribution of clay mineral associations in sections of the studied sites revealed a somewhat unusual increase of the polymineral complex of detrital clay upwards through the drilled interval (beginning from the middle Eocene/Miocene up to the Pleistocene), along with increasing depth water. This may testify not only to fluctuations of the oceanic bottom, but to intensification of the shore erosion and washing away of clay material as a result of sea-level variations.

4) Abrupt changes of quantitative clay mineral ratios in the studied sections of Pleistocene sediments, combined with unsorted clastic material and diversity of minerals of the sandy-silty fraction, indicate appreciable participation of transportation by drift ice of not only coarse-detrital, but also finer clay material in the process of sedimentation. However, the intensity of ice transport in the regions studied was not the same. If coarser clastic material of large pieces of drift were supplied to the Rockall Plateau Pleistocene sediments, only small pieces of ice with less-coarse silty-clayey material reached the Bay of Biscay. This conclusion is well confirmed by the position of the boundary of drift ice distribution that, in the Pleistocene, passed far southwards to $40^{\circ}$ to $43^{\circ} \mathrm{N}$ latitude (Barasch, 1974).

\section{REFERENCES}

Barasch, M.S., 1974. Sea ice boundary in the North Atlantic in upper Pleistocene, Oceanology, v. 14, no. 5.

Biscaye, P.E., 1964. Mineralogy and sedimentation of the deep-sea sediment fine fraction in the Atlantic Ocean and adjacent seas and oceans, Department of Geology, Yale University, Geochemistry Technical Report 8.

Brindley, G.W., and Mering, J., 1951. Diffractions by random layers, Nature, v. 161, p. 774.

Drits, V.A., and Sakharov, B.A., 1976. X-ray structural analysis of mixed-layer minerals, Transactions of GIN Acad. Sci., v. 295, Izdat. "Nauka"' (in Russian).

Gradusov, B.P., 1975. Minerals with the mixed-layer structure in Scils, Izdat. "Nauka"' (in Russian).

Griffin, J.J., Windom, H.L., and Goldberg, 1968. The distribution of clay minerals in the World Ocean, Deep-Sea Res., v. 15, p. 433-459.

Kossovskaya, A.G., and Drits, V.A., 1971. Types of hydromicas of sedimentary rocks and their genetic importance. In Epigenesis and its mineral indicators: Moscow (Nauka), Geological Institute Acad. Sci. of the USSR, Trans. v. 238.

Kossovskaya, A.G., Drits, V.A., and Alexandrova, V.A., 1963. On trioctahedral micas in sedimentary rocks. Internat. Clay Conference. Proceed. Conf. at Stockholm, Sweden, (Pergamon Press), v. 2, p. 147-171.

MacEwan, D.M., 1955. A study of interstratified illitemontmorillonite clay, Clays and Clay Minerals, v. 4.

Mering, J., 1950. Interstratified clay minerals, Trans. 4th Internat. Congr. Soil. Sci., Amsterdam.

Micheev, V.I., 1957. Roengenographical identification layer minerals: Leningrad (Nedra).

Rateev, M.A., 1969. Authigenic clay formation in volcanigenicsedimentary rocks, Proceedings Internat. Clay Conf., Tokyo, v. 2.

Rateev, M.A., and Gradusov, B.P., 1970. The structural row of mixed-layer minerals from Ordovician-Silurian metabentonites of the Baltic region, Transactions of the USSR Acad. Sci., v. 195 , no. 5 (in Russian).

Rateev, M.A., Gorbunova, Z.N., Lisitzyn, A.P., and Nosov, G.I., 1968. The distribution of clay minerals in the oceans, Sedimentology, v. 13. 
Reynolds, R.C., 1967. Interstratified clay Systems: Calculation of the total one-dimensional diffraction, Amer. Mineralogist, v. 52 .

, 1968. The effect of particle size on apparent lattice spacing, Acta Crystallogr., A 24.

Rittman, A., 1960. Vulkane und ihre Tatigkeit: Stuttgart. 2 Auff.

Sato, M., 1965. Structure of interstratified (mixed-layer) mineral, Nature, v. 208, no. 5005.

Shutov, V.D., Katz, M.Ya., Drits, V.A., et al., 1972. Crystallochemical heterogeneity of glauconite as depending on the condi- tions of its formation and post-sedimentary changes, Internat. Clay Conf., Madrid.

Shutov, V.D., Katz, M.Ya., Drits, V.A., Sokolova, A.L., and Kazakov, G.A., 1975. Crystallochemistry of glauconite as an indicator of facial conditions of its formation and postsedimentary changes, Crystallochemistry of minerals and geological.

Strakhov, N.M., 1976. Problems of geochemistry of the recent present-day oceanic lithogenesis. Transactions of GIN, USSR Acad. Sci., v. 292, Izdat. "Nauka" (in Russian). 